\title{
Assessing the factors influencing clients' impulsive information seeking behaviour in using information resources and services of the academic library
}

\author{
Mojtaba Kaffashan Kakhki ${ }^{1}$, Hadi Harati ${ }^{2}$ and Yaser Aseman Doreh ${ }^{2}$ \\ ${ }^{1}$ Department of Knowledge and Information Science, \\ Ferdowsi University of Mashhad, IRAN \\ ${ }^{2}$ Department of Acquisition, The Information Center and Central Library, \\ Ferdowsi University of Mashhad, Mashhad, IRAN \\ ${ }^{3}$ Department of Management, \\ Ferdowsi University of Mashhad, Mashhad, IRAN \\ e-mail: *kafashan@ferdowsi.um.ac.ir (corresponding author); \\ harati-ha@um.ac.ir; yaser.asemandoreh@mail.um.ac.ir
}

\begin{abstract}
The purpose of the present study was to identify and examine the factors that influence the library clients' impulsive behaviour in using resources and services in an academic library. A survey research on the students population of Ferdowsi University of Mashhad in Iran was designed. A researcherdeveloped questionnaire was used for data collection. After determining the validity and reliability of the research instrument, the questionnaire was distributed to 380 students based on a stratified random sampling procedure. Structural Equation Analysis, Path Analysis and the Linear Structural Relation (LISREL) software were used for data analysis. The results showed that (a) the time available to the students, and their interest in books and libraries, bring about surfing enjoyment and make the library a more enjoyable place for them; $(b)$ individual features influence the students' tendency towards impulsive use; (c) environmental features of the library directly affect students' positive emotions and impulsive using behaviour, and indirectly affect it through their positive emotion; and (d) Surfing enjoyment had a direct effect on the students' positive emotion and their tendency towards the impulsive use of the library resources and services. The direct relationship between the students' positive emotion and their tendency towards impulsive use was not confirmed. However, the results of the path analysis showed a direct and significant effect of the positive emotion on the impulsive use of the library resources and services in the selected population.
\end{abstract}

Keywords: Information-seeking behaviour; Impulsive behaviour; Academic libraries; Surfing enjoyment; Information resources and services

\section{INTRODUCTION}

Library clients' behaviour of using information resources or services can be divided into two general categories, i.e. of 'planned' and 'impulsive' behaviour. Planned behaviour, as Ajzen (2006) suggested, may involve a deliberate process of searching for information 
resources via search systems, on shelves, or in various sections of the library to use its services based on a predetermined decision. As defined in the field of marketing (Clover 1950; Rook 1987; Kim 2003; Burnett 2006), impulsive use of information resources or library services may indicate the immediate decision to use the services, but not already planned. Such information-seeking behaviours are momentary and may not be relevant to the clients' basic needs.

Previous studies on information-seeking behaviour (Thanuskodi 2009; Gowda and Shivalingaiah 2010; Kumar, Salmani, and Baweja 2014; Ngozi, Uche, and Ejiro 2015; Mohd Saad and Zainab 2009; Zhong et al. 2018) had investigated the major factors that affect the shaping of information-seeking behaviour in the clients of libraries or information organizations based on some planned patterns. However, it seems that the behavioural aspects of the clients of libraries have some other latent angles, whose formation can be studied by applying the patterns common in the field of marketing. Accordingly, the clients' impulsive behaviour, which can play a decisive role in expanding the use of resources and services or promoting the habit of using libraries especially in developing countries, is an issue worthy of investigation in the information-seeking behaviour of the library clients.

If students, researchers, or faculty members use information resources or use walk-in and/or remote services in the academic libraries only when they need them, it is probable that many of such resources and services will be left out of use and the budget spent on producing and collecting them will not be justifiable. Therefore, the clients' impulsive behaviour can be used to encourage them to use the information resources and services in the academic libraries to become internalized as a dominant and planned behaviour in the long run. In such circumstances, it is expected that the studying level of the library clients or the degree of their use of a wide range of services will also increase in future.

Based on the statistics reported by the Iranian officials regarding the low reading percapita (Salari 2012; Vaezi 2013; Qasim and Noormohammadi 2016) or the clients' low reference to libraries (Brindesi, Monopoli, and Kapidakis 2013; Mohammadzadeh and Bozorgi 2013), it is particularly important that researchers focus on new marketing techniques, such as assessing the factors that influence impulsive behaviours to develop a reading habit and making more use of library environments, especially the academic ones. According to Mohan, Sivakumaran and Sharma (2013), who studied the impulsive behaviour, clients do not decide to use the library resources and services beforehand, but rather are encouraged to use them by the existing drives in the library environment. These drives may lead to the development of library accessibility, thus creating in the long run, an immediate, intense, and relatively sustainable desire to use libraries within the target community. Though important, the clients' impulsive behaviour of using library resources and services is a less researched area. Findings of previous studies, as well as lack of extensive studies on this topic in the context of academic librarianship well justify the conduct of the present research. This study seeks to identify and examine the factors that influence the clients' impulsive behaviour of using library resources and services, and to exacerbate the occurrence of such behaviours. In this study, information resources is referred to the print and electronic books, periodicals, audiovisual materials, and theses. Information services is referred to the activities of an academic library in serving clients, including workshops, information consultancy, study room facilities, and other electronic information services. To address the purpose of the study, the following research questions are formulated: 
(a) What are the influencing factors in the clients' impulsive behaviour of using the resources and services of an academic library?

(b) To what extent does each of the factors influence the clients' impulsive behaviour of using the resources and services of an academic library?

\section{THEORETICAL BACKGROUND AND LITERATURE REVIEW}

Previous studies especially in the field of marketing (Graa and Dani-Elkebir 2012; Mohan, Sivakumaran, and Sharma 2013; Floh and Madlberger 2013; Ozer and Gultekin 2015; Xiang et al. 2016), reported a variety of factors that are influential in examining customers' degree of impulsive behaviour based on their shopping behaviours. In defining impulsive behaviour, Rook and Hoch (1985) have focused on the emotional and cognitive aspects of the customers engaged in impulsive shopping. In doing so, they have defined it as a momentary emotional and cognitive behaviour while shopping. For Clover (1950), Rock (1987), Kim (2003) and Burnett (2006), impulsive behaviour has no prior intentions and plans, and is decided momentarily and is driven by excitement and motivation. According to Stern (1962), such impulsive behaviours are a break from the usual patterns of behaviour. In fact, the focus of attention is individuals' impulsive behaviour and takes into consideration the incentives that trigger their impulsive behaviour. More importantly, the results of a study by Darrat and Amyx (2016) show that an individual's impulsive behaviours can indirectly lead to compulsive or enduring ones, through their anxiety.

Insufficient research conducted in the area of information behaviour in libraries, information centres, overemphasis on planned behaviours (Gowda and Shivalingaiah 2010; Mavodza 2011; Kumar and Tholkappian 2013; Haque, Rahman, and Ajimuddin 2016; Khan, Ahmad, and Khan 2017; Superio et al. 2018; Thindwa, Chawinga, and Dube 2019) and only a study carried out in the area of clients' impulsive behaviour (Harati et al. 2019) justify the conduct of research on library clients' emotional and cognitive aspects, clients' immediate decision-making driven by excitement and motivation, and the influence of incentives on clients' behaviour.

\section{Tendency Towards Impulsive Use of Library Resources and Services}

Tendency towards the impulsive use of organizations' resources and services is the outcome of individuals' emotional response (Xuanxiaoqing, Yang and Huang 2012) and is attributed to the extent to which consumers display immediate, unplanned and thoughtless behaviour (Vänniä 2013). The findings of the previous studies have shown that individuals differ in their degree of tendency towards impulsive behaviours (Rook and Fisher 1995). According to Beatty and Ferrell (1998) and Jones et al. (2003), a direct and significant relationship is conceivable between tendency towards impulsive use and the shaping of this behaviour. Impulsivity (Ozer and Gultekin 2015; Chen and Wang 2016; and Darrat, Darrat, and Amyx 2016), extraversion, neuroticism, and their influence on individuals' tendency towards impulsive behaviours (Olsen et al. 2016), as well as individuals' para-social interactions (Xiang et al. 2016) are mentioned as the factors that influence the shaping of the tendency towards impulsive behaviours.

Although many studies have examined individual tendency and cognitive styles in the area of information-seeking behaviour (Riding and Rayner 1998; Salarian, Ibrahim, and Nemati 2012), the relationship between these traits and clients' impulsive behaviours has not been fully explored yet. 


\section{Time Factor}

Time is an effective factor in shaping information-seeking behaviours. Consistent with the findings of Beatty and Ferrell (1998), Virvilaite, Saladienè, and Bagdonaite (2009), Wu and Han (2010), Husnain, Rahman and Sid (2018) and Zhao et al. (2019), having enough time has a direct and significant effect on individuals' impulsive behaviour to use the available resources or services. According to Xu (2007), the relationship between environment and individuals' emotional state is moderated through personality factors such as motivation, and through situational factors such as time pressure. Graa and Dani-Elkebir (2012) emphasized the importance of the available time factor in shaping individuals' impulsive behaviours. In line with these studies, the findings of those by Wannberg and Banas (2000) and Foroughi et al. (2013) show that the situational variable of time has an effect on triggering individuals' impulsive behaviours or their flexibility. Harati et al. (2019) also identified the variable of time as one of the factors that influence the impulsive behaviours of library clients.

Hence, it seems that a direct and significant relationship exists between the variable of time and impulsive behaviours. Although several studies in the field of librarianship and information science (Burkett 1976; Veatch 1987; Pors 2005; Halder, Roy, and Chakraborty 2010; Harati et al. 2019) have directly or indirectly dealt with the variable of time, no research investigating and assessing the effect of time on library clients' impulsive behaviours was found.

\section{Degree of Individual's Tendency Towards Books and Libraries}

An important indicator of cultural development in the developed societies, whose strength and weakness is affected by the intellectual and ideological underpinnings of the societies, is the reading per-capita. Based on previous research in Iran, many factors play an inhibitive role in books, book reading, and library usage. These include the inability of the educational system in showing the true value of libraries and the reading habit (Katebi 1973), existence of the culture of superficial reading in the society (Soltani 1978), weak creative thinking of the Iranian youth in the educational system (Samaniyan 1998), lack of cultural habits such as donating books (Mohseni Kabir 1999; Amani 2000), lack of belief in the influence of libraries and resources on the economic, social and cultural growth (Safi 2001) and weak culture of study and limited use of libraries affected by lack of belief in the true value of books and libraries (Ghanavizchi and Davar Panah 2008; Kiani, Rezaei Sharifabadi, and Sam 2010).

In this study, the variable "individual's tendency towards books and libraries" is equated with the variable "product involvement" in the field of marketing. In line with Islam and Tashchian (1985), product involvement refers to an individual's personal interest prior to making any behavioural decisions. Engel, Blackwell, and Miniard (1994), further, define product involvement as a special environmental condition that is triggered by personal knowledge or interest in a product or service. Zaichkowsky (1994) also defines product involvement as individuals' perceived relation with an object or service (such as books and libraries) based on their innate needs, interests, and values. Similarly, Kapferer and Laurent (1985) showed that those who are mentally more involved with a particular product, experience more pleasure in using that product or service. For Jones et al. (2003), product involvement is an important factor in shaping individuals' impulsive behaviours. This result corroborates the results of other studies on topics such as fancy shopping and dilettantism (Sharma, Sivakumaran, and Marshall 2010), interest in shopping fashion-oriented products (Park, Kim, and Forney 2006), and felicific shopping of new products (Harmancioglu, Finney, and Joseph 2009). The present study investigates the extent of the library clients' 
tendency towards books and libraries to assess its effect on their impulsive behaviour of using the resources and services of academic libraries. This approach helps to address the effectiveness of the aforementioned variables, and is supposed to fill the research gaps in this area, especially in relation to academic libraries.

\section{Environmental Features}

For Ailawadi and Keller (2004), environmental features are the physical (design, ambient lighting, and layout) and social features (staff accessibility, staff attitude towards clients) that exist in the interior space of a service center. Applebaum (1951, cited in Hoyer and MacInnis 2008) was the first researcher who proved that impulsive shopping might result from the incentives posed to the consumer from within the company. Houston and Rothschild (1978), Bloch and Richens (1983), Jiang and Wang (2006) and Said et al. (2016) also found that environmental features attract individuals' attention, their satisfaction, and encourages them to use products or services.

As Donovan et al. (1994) put forward, felicific environments motivate individuals to spend a longer time there or to use specific services unplanned. Previous studies (Gupta, Heng, and Sahu 2009; Mihić and Kursan 2010; Graa and Dani-Elkebir 2012; Husnain, Rahman and Sid 2018) uphold the positive relationship between environmental features and tendency towards impulsive behaviours. In the field of librarianship and information science, a number of studies have also explored the environmental features of libraries (Veatch 1987; Shill and Tonner 2003, 2004; Sufar, Talib, and Hambali 2012; Harati et al. 2019). However, no studies investigating the influence of environmental features on the clients' impulsive information-seeking behaviour were found.

\section{Individual Features}

According to Weinberg and Gottwald (1982), impulsive behaviour is a type of multidimensional behaviour, originated from individual and personality traits. Beatty and Ferrell (1998) and Peck and Childers (2006) showed that individual features increase the likelihood of impulsive behaviours. In other studies, Youn and Faber (2000), Kacen and Lee (2002) and Tremblay (2005) pointed out the lack of control and its role in impulsive shopping behaviour. The findings of Kacen and Lee (2002) and Tuyet et al. (2003) showed a positive correlation between tendency towards individualism (as one individual trait) and impulsive shopping .

Elliott (1994) believes that individuals' social self-esteem, which is influenced by their personality traits, plays an important role in developing impulsive behaviours. According to Mohan, Sivakumaran, and Sharma (2013) and Sofi and Najar (2018), personality traits influence individuals' impulsive behaviours through motivation and positive emotion. In addition, attention to individuals' personality traits in the library-related research (Halder, Roy, and Chakraborty 2010; O'Brien, Dickinson, and Askin 2017; Harati et al. 2019; Ahmed, Rehman, and Sheikh 2019; Thindwa, Chawinga, and Dube 2019) shows the importance of this variable in using library resources and services. Therefore, the necessity of assessing the influence of individuals' features on developing the library clients' impulsive behaviours is justifiable.

\section{Surfing Enjoyment}

Hedonism is a subjective and individual variable, perceived through joy, fun, and entertainment as a factor in achieving the goal (Sherry 1990). Accordingly, tendency towards consumerism and hedonism can focus more on emotions and motivational drives than on the functional benefits of the product or service (Sharma, Sivakumaran, and 
Marshall 2010). In other words, hedonism remarks emotional drives (Hirschman and Holbrook 1982) as well. Individuals with experience in felicific shopping or surfing are more willing to repeat it and develop impulsive behaviours (Jarboe and McDaniel 1987; Beatty and Ferrell 1998; Koufaris 2002; Brown, Pope, and Voges 2003).

In the present study, surfing enjoyment refers to clients' enjoyment and satisfaction the time of visiting the library environment. Some empirical studies have alleged that emotional state or perceived pleasure affects individuals' surfing activities, hence are influenced more by the existing drives (Bellenger, Robertson, and Greenberg 1977; Bellenger and Korgaonkar 1980). Some have also stated that surfing is stimulated by recreation (Bloch, Sherrell, and Ridgway 1986; Rowley 2002; Moe 2003).

Baloch, Sherrell, and Ridgway (1986), Bloch, Ridgway, and Sherrell (1989) and Wakefield and Baker (1998) found a significant relationship between emotional state and explorative search behaviour or a tendency towards staying longer in a recreation centre for surfing. The results of some previous studies such as Koufaris's Flow Theory (Koufaris, Kambil, and LaBarbera 2001; Koufaris 2002) as well as Graa and Drai-Alkebir's (2012) demonstrated that surfing enjoyment has a positive effect on impulsive behaviours.

In a similar vein, Floh and Madlberger (2013) revealed that surfing enjoyment leads to online impulsive shopping behaviours in individuals. A number of related studies on surfing enjoyment have also been conducted. These include web surfing with the aim of using the Internet (Teo 2001), children's joy of using and playing computer games (Mumtaz 2001), the emotional and joyful aspects of information searching (Fulton 2009), or children's surfing in the interface of digital libraries with the aim of using and enjoying such libraries (Wu 2015). However, in these studies, the relationship between impulsive behaviours and clients' surfing in libraries is not addressed.

\section{Positive Emotion}

Researchers show that positive emotion has a direct and positive relationship with individuals' performance (Isen and Reeve 2005; Bronstein 2014; Ghavidel and Gilvari 2016) or their information-seeking behaviour in libraries (Lopatovska and Arapakis 2011). Positive emotion is a personality trait that makes people delighted, satisfied or interested in performing certain tasks. It is defined as individuals' emotional state, and their reactions to the environmental drives (such as the desired products, incentives to buy, etc.) (Park, Kim, and Forney 2006).

For Beatty and Ferrell (1998), positive emotions reflect individuals' level of enthusiasm, awareness, and interactivity. Customers with more impulsive shopping feel more positive (Donovan and Rossiter 1982) and employ less complicated processes to make decisions for shopping (Ajzen 1985). In addition, the consumers' previous shopping experiences influence their emotions and are correlated with their impulsive behaviour motivation (Hausman 2000). Thus, emotions strongly stimulate impulsive behaviour (Park, Kim, and Forney 2006; Sharma, Sivakumaran, and Marshall 2010; Imbayani and Novarini 2018; Ahmad et al. 2019; Maulana, Mukhlis, and Novalia 2019). As such, feeling positive about the library environment makes the library clients more willing and eventually makes them use the available resources and services impulsively. 


\section{CONCEPTUAL FRAMEWORK AND HYPOTHESES OF THE RESEARCH}

Against the above theoretical and empirical backdrop, the interrelationship between the variables is proposed as the conceptual framework of the research. This framework makes it possible to evaluate and assess the importance of the influence of these factors on the library clients' impulsive behaviour. In addition, it can be employed as a useful tool for examining the library clients' behaviour. Figure 1 illustrates the conceptual framework.

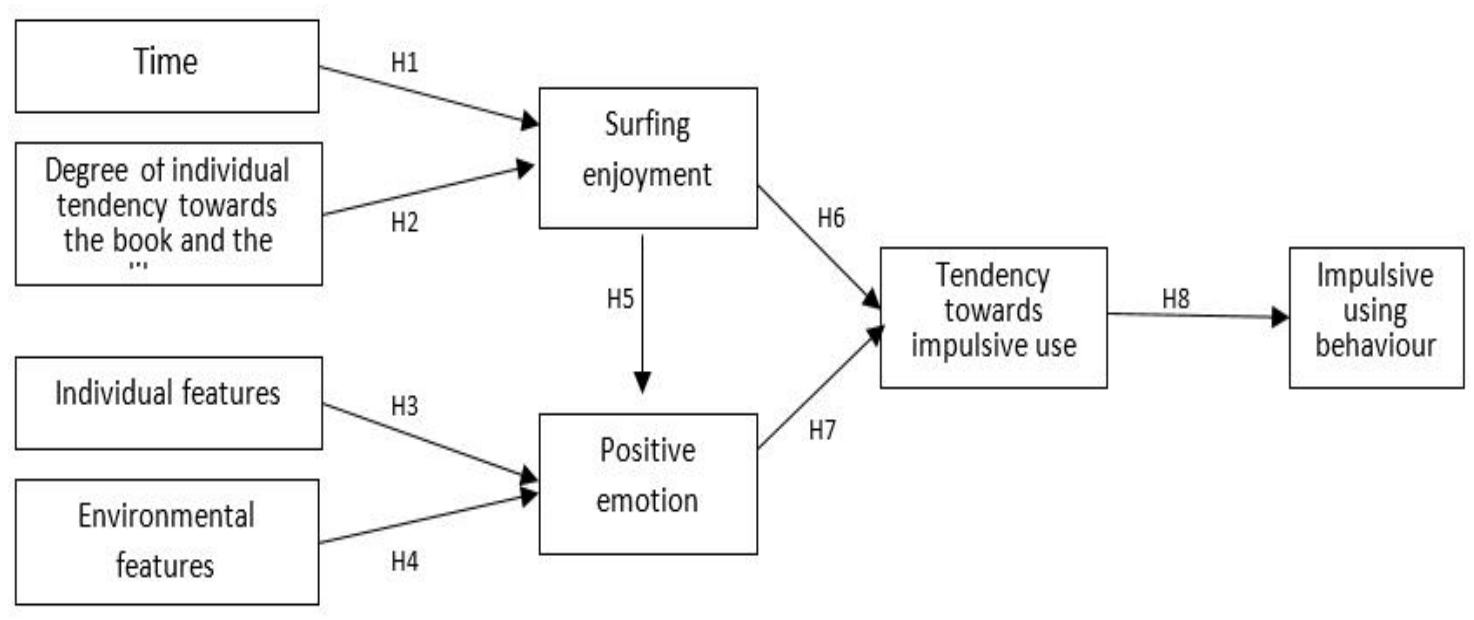

Figure 1: Conceptual Framework of the Research

To assess the identified factors that affect the clients' impulsive behaviour of using the resources and services of the academic libraries and to answer the research questions, the following eight hypotheses were formulated:

H1: Time available has a direct and significant effect on library surfing enjoyment.

H2. The degree of individuals' interest in books and libraries has a direct and significant effect on the surfing enjoyment in the library.

H3. Individual features have a direct and significant effect on individuals' positive emotion about the library.

H4. Environmental features have a direct and significant effect on individuals' positive emotion towards the library.

H5. Surfing enjoyment has a direct and significant effect on individuals' positive emotion about the library.

H6. Surfing enjoyment has a direct and significant effect on individuals' tendency towards impulsive use of the library.

H7. Individuals' positive emotion about the library has a direct and significant effect on their tendency towards the impulsive use of the library.

H8. Tendency towards impulsive use has a direct and significant effect on individuals' impulsive use of the library. 


\section{METHOD}

This study employed a survey-analytical research design. The statistical population of this study consisted of 24,453 students studying in all levels and fields at Ferdowsi University of Mashhad, one of the two major universities in Iran. To reduce the Sampling Error Variance (SEV) and increase the sample representativeness, due to using the Path Analysis method, and considering 10 observations for each of the 38 items of the questionnaire, a total of 380 students were selected as the sample size. The data were collected based on: (a) stratified random sampling procedure appropriate for the size of the population (one stratum for each degree level); (b) random sampling within each stratum. The ratio of the number of students at each degree level to the total number of students was calculated and the questionnaire was distributed randomly with the same ratio among the students at each degree level.

The tool used for collecting data was a researcher-developed questionnaire ${ }^{1}$ that was designed on the basis of the related literature and the comments given by the respondents and experts. It consisted of two sections: the first section (4 questions), was devoted to the respondents' demographic information. The second section (38 item statements) that was designed to assess the respondents' perceptions of the research variables on a five-point Likert Scale ( 1 for 'strongly disagree' to 5 for 'strongly agree'). Table 1 lists the number of item statements devoted to each variable in the questionnaire.

Table 1: Number of Items for Each Variable in the Questionnaire

\begin{tabular}{l|c}
\hline \hline \multicolumn{1}{c|}{ Variables } & Number of item statements \\
\hline \hline Time & 5 \\
Environmental features & 6 \\
Individual features & 5 \\
Degree of an individual tendency towards books and libraries & 4 \\
Surfing enjoyment & 4 \\
Tendency towards impulsive use & 4 \\
Impulsive using behaviour & 4 \\
Positive emotion & 6 \\
\hline \hline
\end{tabular}

The questionnaire was examined for its face and content validity. As for content validity, it was valid because the criteria used in the design of the questionnaire were based on the theoretical foundations, extracted from the previous studies and also were confirmed by experts in terms of quantity and quality. As for face validity, it proved valid because experts endorsed the ability of the assessment tool in terms of clarity and ambiguity of the items. The reliability of the questionnaire was also calculated by administering a pre-test to 30 subjects and by using Cronbach's alpha coefficient which was 0.89 for the entire questionnaire. None of the research variables had a Cronbach's alpha coefficient of smaller than 0.70 .

The method used for data analysis was Structural Equation Modeling (SEM). SEM is a multivariate technique that combines features of factor analysis, regression, and path analysis. This method makes hypotheses testing in the librray and information science research possible; while fitting the theoretical model of the research, it can modify the measurement errors of the model in relation to the data extracted from the research

\footnotetext{
${ }^{1}$ The instrument is available from the corresponding author upon request.
} 
sample and design the final model according to the observed conditions. To analyze the data, the Linear Structural Relation (LISREL) 5.8 Software was used.

\section{RESULTS}

\section{Demographic Results}

Of the 380 respondents participating in this study, 184 were male and 196 were female. With regard to age, most of the participants $(325,85.5 \%)$ were within the age range of 18 to 30 . With regard to educational background, $159(41.8 \%)$ participants were studying in humanities, $37(9.8 \%)$ in sciences, $115(30.3 \%)$ in engineering, 69 (18.1\%) in agriculture, natural resources and veterinary medicine. Of the total number of participants, 181 (47.6\%) were studying for a bachelor's degree, 141 (37.1\%) for a master's degree and 58 (15.3\%) for a doctoral degree. Table 2 presents the demographic information.

Table 2: Demographic Information of the Respondents

\begin{tabular}{l||l||c||c}
\hline \hline \multicolumn{1}{c||}{ Category } & \multicolumn{1}{c||}{ Item } & Frequency & Percent (\%) \\
\hline \hline Gender & Male & 184 & 48.4 \\
& Fge & 196 & 51.6 \\
& $18-30$ & 325 & 85.5 \\
& $31-40$ & 46 & 12.1 \\
& 41 or older & 9 & 2.4 \\
\hline \multirow{2}{*}{ Department of Education } & Humanities & 159 & 41.8 \\
& Science & 37 & 9.8 \\
& Engineering & 115 & 30.3 \\
& Agriculture, Natural Resources, & 69 & 18.1 \\
& Veterinary Medicine & & \\
\hline \multirow{2}{*}{ Educational degree } & Undergraduate & 181 & 47.6 \\
& Masters & 58 & 37.1 \\
& PhD & 15.3 \\
\hline \hline
\end{tabular}

\section{Measurement Model Results}

To determine the adequacy of the theoretical model fit to the data, fitting indexes were employed including relative Chi-square $\left(x^{2} / d f\right)$ that was calculated through the simple dividing of Chi-square value by the degree of freedom of the model. The value acceptable for this index is smaller than 2.5. The next index is RMSEA ${ }^{1}$ which, in acceptable models, has values smaller than 0.08 . Other indexes are $\mathrm{AGFI}^{2}$ and $\mathrm{GFI}^{3}$, for which the acceptable values should be greater than 0.9 (Hooman 2005).

Table 3 presents the values of the theoretical model fit indexes. Based on this output, the pattern in question is not confirmed. In addition, based on the value obtained from the RMSEA index, which is greater than the acceptable value (0.08), it is concluded that the degree of approximation in the population is very large; thus the model should not be confirmed.

\footnotetext{
${ }^{1}$ Root mean squared error of approximation

${ }^{2}$ Adjusted Goodness of Fit Index

${ }^{3}$ Goodness-for-fit Index
} 
Kaffashan Kakhki, M., Harati, H. \& Aseman Doreh, Y.

Table 3: Fitness Indicators of Research Primary Model

\begin{tabular}{|l|c|l|c|}
\hline \multicolumn{1}{|c|}{ Factor } & Obtained Value & Acceptable Value & Result \\
\hline$\chi^{2} /$ df & 10.16 & Smaller than 2.5 & Weak fit \\
\hline RMSEA & 0.16 & Smaller than 0.08 & Weak fit \\
\hline GFI & 0.89 & Larger than 0.90 & Weak fit \\
\hline AGFI & 0.78 & Larger than 0.90 & Weak fit \\
\hline
\end{tabular}

The results obtained from the theoretical model fit (the $t$-values and the path coefficient between variables) are shown in Figure 2 . In case the $t$-value obtained is smaller than 1.96, the corresponding hypothesis is not confirmed. As shown in Figure 2, hypotheses 3, 7 and 8 were not confirmed.

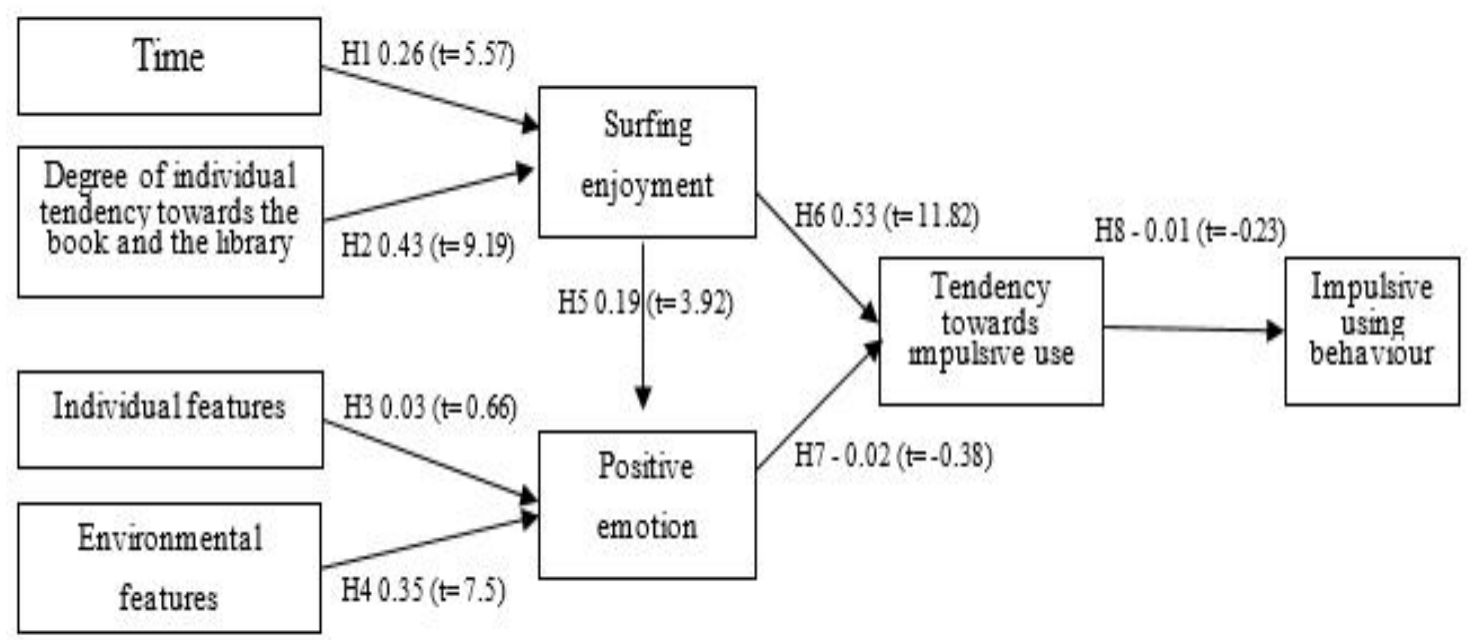

Figure 2. Results of the Theoretical Model Fit (path coefficient and $t$-values)

To determine the main source of non-fit model, first the paths of individual features to positive emotion, positive emotion about tendency towards impulsive use, and tendency towards the impulsive using behaviour (not significant) were eliminated and then adjustment indexes were used instead. Adjustment indexes revealed that a significant relationship exists between the environmental features and impulsive using behaviour. After that, by releasing the paths of individual features to tendency towards and positive emotion about impulsive using behaviour, a significant decrease was resulted in the amount of $x^{2}$ and created the data fit model. Table 4 presents the goodness-for-fit indexes of the research's final model.

Table 4: Fitness Indexes of the Research's Final Model

\begin{tabular}{|l|c|l|l|}
\hline \multicolumn{1}{|c|}{ Factor } & Obtained Value & \multicolumn{1}{c|}{ Acceptable Value } & \multicolumn{1}{c|}{ Result } \\
\hline$\chi^{2} /$ df & 1.70 & Smaller than 2.5 & Acceptable \\
\hline RMSEA & 0.043 & Smaller than 0.08 & Acceptable \\
\hline GFI & 0.98 & Larger than 0.90 & Acceptable \\
\hline AGFI & 0.96 & Larger than 0.90 & Acceptable \\
\hline
\end{tabular}


In the research's final model (Figure 3), some of the relationships determined in the conceptual model were not confirmed and new relationships were identified between the variables. Accordingly, tendency towards impulsive use had no effect on individuals' impulsive using behaviour ( $t=-0.23$ ). Individual features did not have any effect on the students' positive emotion about the library $(t=0.66)$, but they did influence the tendency toward the impulsive use $(t=7)$. As shown in Figure 3, environmental features not only had an effect on the students' positive emotion about the library ( $t=7.52)$ but also directly influenced impulsive using behaviour ( $t=3.79$ ). In addition, the students' positive emotion about the library did not have any effect on their tendency towards impulsive using behaviour ( $t=-0.38$ ), but it directly influenced their impulsive using behaviour ( $t=3.79$ ).

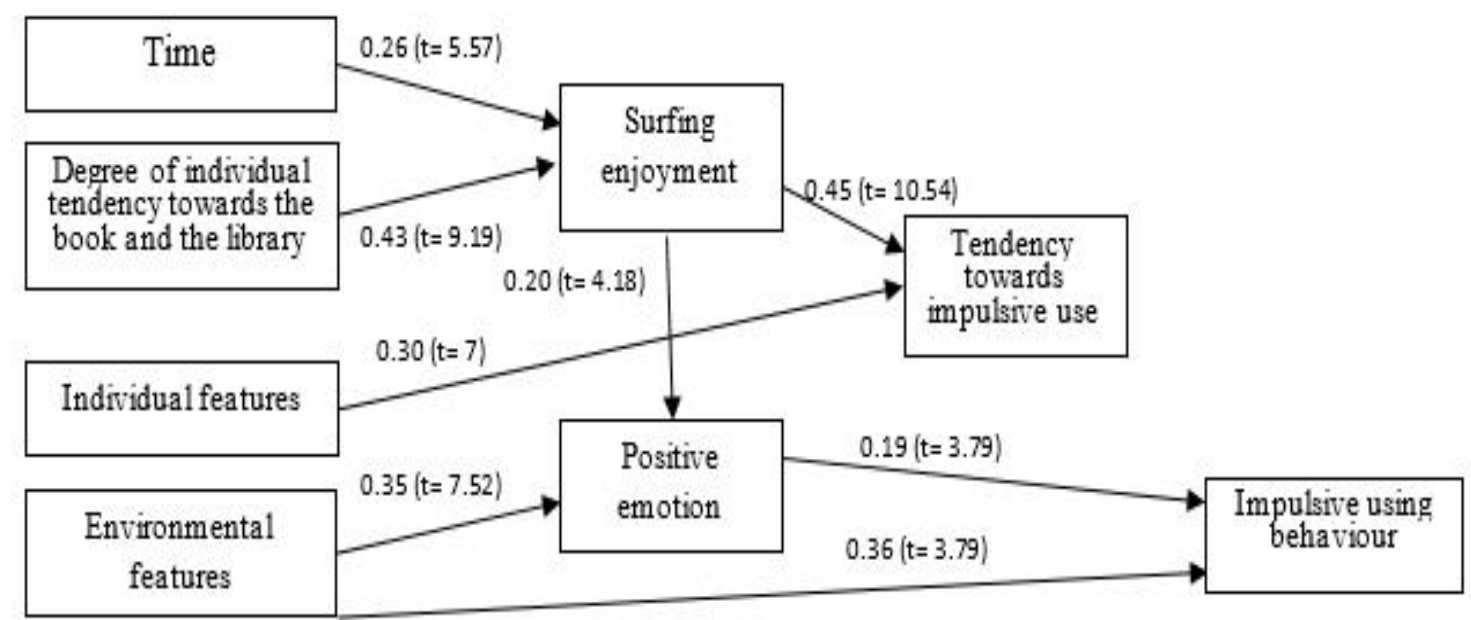

Figure 3: Structural Equation (the path coefficients and $t$-values) of the Research's Final Model

\section{Results of Hypotheses Testing}

With regard to the final model of the research (Figure 3), Table 5 presents the results obtained from testing the research hypotheses. The hypotheses with a $t$-value of greater than 1.96 as well as a positive impact factor had a significant and positive effect.

\section{Answering the Research Questions}

The first research question can be answered based on the results obtained and the final model of the research (Fig. 3). Accordingly, environmental features, positive emotion, time, degree of personal interest in books and libraries, and surfing enjoyment were identified as the factors affecting the clients' impulsive behaviour in using academic library resources and services. Environmental features and positive emotion about libraries directly influence the clients' impulsive behaviour in using library resources and services. Time, degree of individuals' interest in books and libraries, and surfing enjoyment indirectly, through positive emotion, influence the clients' impulsive using behaviour.

To answer the second research question, the direct and indirect coefficients as well as the total effect of the variables of the research's final model affecting the clients' impulsive behaviour were calculated (Table 6). 
Kaffashan Kakhki, M., Harati, H. \& Aseman Doreh, Y.

Table 5: Results of the Hypotheses Testing and Fitness of the Research Model

\begin{tabular}{|c|c|c|c|c|}
\hline & Hypotheses & Path & $t$-value & Result \\
\hline 1 & $\begin{array}{l}\text { Time available has a direct and significant } \\
\text { effect on surfing enjoyment }\end{array}$ & 0.26 & 5.57 & Supported \\
\hline 2 & $\begin{array}{l}\text { Degree of tendency towards books and } \\
\text { libraries has a direct and significant effect on } \\
\text { surfing enjoyment }\end{array}$ & 0.43 & 9.19 & Supported \\
\hline 3 & $\begin{array}{l}\text { Individual features have a direct and } \\
\text { significant effect on positive emotion }\end{array}$ & 0.03 & 0.66 & Not supported \\
\hline 4 & $\begin{array}{l}\text { Environmental features have a direct and } \\
\text { significant effect on positive emotion }\end{array}$ & 0.35 & 7.52 & Supported \\
\hline 5 & $\begin{array}{l}\text { Surfing enjoyment has a direct and } \\
\text { significant effect on positive emotion }\end{array}$ & 0.20 & 4.18 & Supported \\
\hline 6 & $\begin{array}{l}\text { Surfing enjoyment has a direct and } \\
\text { significant effect on tendency towards } \\
\text { impulsive use }\end{array}$ & 0.45 & 10.54 & Supported \\
\hline 7 & $\begin{array}{l}\text { Positive emotion has a direct and significant } \\
\text { effect on tendency towards impulsive use }\end{array}$ & -0.02 & -0.38 & Not supported \\
\hline 8 & $\begin{array}{l}\text { Tendency towards impulsive use has a direct } \\
\text { and significant effect on impulsive using } \\
\text { behavior }\end{array}$ & -0.01 & -0.23 & Not supported \\
\hline
\end{tabular}

Table 6: Direct and Indirect Coefficients of Variables of the Research's Final Model

\begin{tabular}{|l|l|c|l|c|}
\hline $\begin{array}{c}\text { Dependent } \\
\text { variable }\end{array}$ & \multicolumn{1}{|c|}{$\begin{array}{c}\text { Affecting factors } \\
\text { (Independent variables) }\end{array}$} & $\begin{array}{c}\text { Direct } \\
\text { effect }\end{array}$ & Indirect effect & Total effect \\
\hline $\begin{array}{l}\text { Impulsive } \\
\text { using } \\
\text { behavior }\end{array}$ & Environmental features & 0.36 & $\left(0.35^{*} 0.19\right)=0.07$ & 0.43 \\
\cline { 2 - 5 } & Positive emotion & 0.19 & - & 0.19 \\
\cline { 2 - 5 } & Surfing enjoyment & - & $\left(0.20^{*} 0.19\right)=0.04$ & 0.04 \\
\cline { 2 - 5 } & Time available & - & $\left(0.26^{*} 0.20^{*} 0.19\right)=0.001$ & 0.001 \\
\cline { 2 - 5 } & $\begin{array}{l}\text { Degree of individuals' tendency } \\
\text { towards books and the libraries }\end{array}$ & - & $\left(0.43^{*} 0.20^{*} 0.19\right)=0.016$ & 0.016 \\
\hline
\end{tabular}

As shown in Table 6, the variables affecting the impulsive using behaviour are the effect of environmental features (0.43), positive emotion $(=0.19)$, surfing enjoyment $(=0.04)$, personal interest in books and libraries $(=0.016)$ and time available $(=0.001)$, respectively. Thus, the environmental features and positive emotion are the most influential variables in the occurrence of impulsive using behaviour in the population under study. In addition, the positive emotion is affected by the environmental features and surfing enjoyment which, in turn, is under the influence of variables such as the degree of individuals' interest in books and libraries as well as the time available. Finally, the time available has the least effect on the library clients' impulsive behaviour.

\section{DISCUSSION}

In this study, the effect of the time available on surfing enjoyment in the library environment was investigated (Hypothesis 1 ). The results indicated that the time available 
not only has a direct and significant effect on the surfing enjoyment in the library environment ( $t=5.57, \beta=-0.26$ ) but also, indirectly through the surfing enjoyment, has an effect on the individuals' positive emotion and their tendency towards impulsive using behaviour. In other words, if the client has enough time to stay in the library, the likelihood of them surfing in the library environment is enhanced. This finding is in line with those by Beatty and Ferrell (1998), Virolite, Saladin and Begonite (2009), Wu and Han (2010), Graa and Dani-Elkebir (2012), Hassan, Rahman and Sayed (2018) and Zhao et al. (2019) in the field of marketing. This finding is consistent with the findings of Barquet (1976), Viatch (1987), Pors (2005), Halder Halder, Roy, \& Chakraborty (2010) and Harati et al. (2019), who examined the positive and significant effect of time on clients' behaviour in the library environment. In the present study the effect of time on the clients' impulsive behaviour in academic library was confirmed.

The effect of the individuals' degree of tendency towards books and libraries on surfing enjoyment was also investigated (Hypothesis 2). The final model of the research confirmed this effect; in other words, the degree of the students' tendency towards books and libraries leads to surfing enjoyment in the library environment $(\mathrm{t}=9.19, \beta=0.43)$. In line with Engel, Blackwell, and Miniard (1994), Zaichkowsky (1994), and Kapferer and Laurent (1985), who emphasized the positive relationship between product involvement and individuals' motivation for using a product or service, the effect of the degree of individuals' tendency towards books and libraries on the clients' impulsive informationseeking behaviour in academic libraries was indirectly (through the surfing enjoyment and positive emotion) confirmed. As a result, the development of methods for motivating individuals to use books and libraries in academic environments can provide an opportunity to make more use of the resources and services of such libraries. Therefore, it can be expected that the students' degree of interest in books and libraries, spending more time on reading books/information resources and visiting the library environment will make them spend more time on library surfing and enjoy it .

In the third hypothesis, the direct relationship between the individual features and positive emotion was not confirmed ( $\mathrm{t}=0.66, \beta=0.03$ ). Thus, it seems that the students' personality, impulsiveness, and autonomy in their activities in the library environment will not make them feel positive about the academic libraries. This findings proved that the individual features have no effect on the positive emotion; this is contrary to the findings of Mohan, Sivakumaran, and Sharma (2013) and Sofi and Najar (2018) who showed that individual variables affect impulsive behaviour through motivation and its positive effect.

The results obtained from testing the fourth hypothesis indicated that the environmental features have a significant and direct effect on the positive emotion ( $t=7.52, \beta=0.35)$. This finding is in line with the findings of Kaur and Singh (2007), Mohan, Sivakumaran and Sharma (2013) and Hussein, Rahman, and Sayed (2018). The studies related to examining the environmental features of libraries in the field of library and information science have mainly focused on the physical environment, buildings and interior space of the libraries (Veatch 1987; Shill and Tonner 2003, 2004; Sufar, Talib, and Hambali 2012), or on the relationship between the environmental features and other variables (Said et al. 2016; Harati et al. 2019). The importance of environmental features is highly emphasized in these studies. In a similar vein, the present study confirmed the positive and significant effect of the environmental features on the students' positive emotion about the library. As such, the environmental features including layout and appearance of the resources, introduction of new books, amount of ambient light, the staff attitude and their availability make students feel positive about the library. 
Moreover, the results of testing the fifth hypothesis showed that the surfing enjoyment has a direct effect on the clients' positive emotion ( $t=4.18, \beta=0.20$ ). Thus, the students' interest in surfing the library environment will bring about emotions such as excitement, enjoyment, motivation, usefulness, and generally positive emotions about the academic libraries. This finding is in line with Park, Kim, and Forney (2006) who proved that fashionorientedness affects the hedonic consumption tendency which, in turn, affects the positive emotion.

In this study, the effect of surfing enjoyment on the students' impulsive use of library resources and services was also examined (Hypothesis 6). As shown in the final model of the research, the surfing enjoyment has a direct and significant effect on the students' impulsive use of library resources and services $(\mathrm{t}=10.54, \beta=0.45)$. Therefore, the students' interest in and enjoyment of the library environment will raise their willingness towards the impulsive use and will help them make abrupt decisions about the resources and services of the academic libraries. This finding is consistent with those of Bloch, Sherrell, and Ridgway (1986), Bloch, Ridgway, and Sherrell (1989), Wakefield and Baker (1998), and Novak, Hoffman, and Yung (2000), who found a significant relationship between emotional status and explorative search behaviour or tendency towards surfing in a recreational center.

The results obtained from testing the seventh hypothesis did not confirm the direct relationship between the positive emotion and the tendency towards impulsive use $(\mathrm{t}=\mathrm{-}$ $0.38, \beta=-0.02$ ). As such, the students' excitement, enjoyment, motivation, usefulness and generally their positive emotions about the library will not lead to a tendency towards the impulsive use of the academic library resources and services. The ineffectiveness of the positive emotion on the tendency towards impulsive use in this study was contrary to the findings of some previous studies (Park, Kim, and Forney 2006; Sharma, Sivakumaran and Marshall 2010; Imbayani and Novarini 2018; Ahmad et al. 2019; Maulana, Mukhlis, and Novalia 2019).

The results of the eighth hypothesis revealed that there was no direct and significant relationship between the students' tendency towards the impulsive behaviour and the impulsive using behaviour ( $\mathrm{t}=-0.23, \beta=0.01$ ). Based on this finding, the tendency towards the impulsive use of the resources and services will not lead to the students' impulsive using behaviour. This finding is inconsistent with some previous studies (Beatty and Ferrell 1998; Jones et al. 2003).

In addition to the results obtained from testing the hypotheses, some relationships beyond the initial model proposed in this study were identified (Figure 1). The results of testing the research's final model (Figure 2) showed that there is a direct and significant relationship between the individual features and the students' tendency towards the impulsive use of library resources and services $(t=7, \beta=0.30)$. This means that the students' individual features, such as personality and impulsiveness, influence their impulsive use of the academic library resources and services. The positive and significant effect of individual features on users' impulsive behaviour (Harati et al. 2019) and other aspects of information-seeking behaviour in library environments were previously confirmed in the field of librarianship and information science.

The path analysis results further showed a direct and significant effect of the positive emotion on the students' impulsive use of library resources and services ( $t=3.79, \beta=0.19)$. This finding is in line with that of Park, Kim, and Forney (2006). In addition, a significant and 
direct relationship was found between the environmental features and the impulsive using behaviour in the research's final model ( $\mathrm{t}=3.79, \beta=0.36$ ). This relationship was previously confirmed (Houston and Rothschild 1978; Bloch and Richins 1983; Donovan et al. 1994).

The above findings highlighted the role of the library environmental features in shaping the impulsive using behaviour of the resources and services. Environmental features not only have a direct and significant effect on the students' positive emotion, but also have a direct and significant effect on the impulsive using behaviour of the resources and services. Therefore, the environmental features of the library seem to play an important role in shaping the students' impulsive use of library resources and services.

\section{CONCLUSION}

The library clients' information-seeking behaviour is directly and indirectly affected by factors that decrease or increase using library resources and services. A less researched aspect of the clients' information-seeking behaviour is their impulsive behaviour. Considering factors that affect the students' impulsive behaviour to develop their use of information resources and services of the academic library seems particularly important to change their behaviour. This study uncovered how some of these factors affect each other, and the degree and importance of the effect of each factor.

It is hoped that the findings of this study will provide a good empirical basis for enhancing productivity and synergy in the development of using the resource and services of the academic library. To reach this goal, academic libraries need to pay more attention to both the planned and impulsive information-seeking behaviours of their clients. Therefore, this study tends to encourage academic libraries to look for ways to enhance their clients' use of information resources and services.

This study also proposes a new approach to study clients' information-seeking behaviour. The proposed model analyzes the direct and indirect relationships of factors affecting the clients' impulsive behaviour, thus can provide a basis for prioritizing and planning of the library administrators to provide optimal conditions for using library resources and services. Finally yet importantly, this study can be considered as a starting point for future research in the field of library clients' impulsive information-seeking behaviour.

\section{ACKNOWLEDGEMENT}

No grant from any public, commercial, or non-profit funding agency was offered for the conduct of this research. We thank the reviewers for their enriching comments to improve the article.

\section{REFERENCES}

Ahmad, M. B., Ali, H. F., Malik, M. S., Humayun, A. A. and Ahmad, S. 2019. Factors affecting impulsive buying behavior with mediating role of positive mood: An empirical study. European Online Journal of Natural and Social Sciences, Vol. 8, no. 1. Available at: http://european-science.com/eojnss/article/view/5510. 
Ahmed, S., Rehman, F. and Sheikh, A. 2019. Impact of personality traits on information needs and seeking behavior of LIS students in Pakistan. Information Discovery and Delivery, Vol. 47, no. 3: 125-134. Available at: https://doi.org/10.1108/IDD-09-20180046.

Ailawadi, K. L., and Keller, K. L. 2004. Understanding retail branding: conceptual insights and research priorities. Journal of Retailing, Vol. 80, no. 4: 331-342. Available at: https://doi.org/10.1016/j.jretai.2004.10.008.

Ajzen, I. 1985. From intentions to actions: A theory of planned behavior. In J. Kuhl \& J. Beckmann (eds.), Action control: From cognition to behavior (pp. 11-39). Berlin, Heidelberg: Springer. Available at: https://doi.org/10.1007/978-3-642-69746-3_2.

Ajzen, I. 2006. Constructing a TPB questionnaire: Conceptual and methodological considerations.

Amani, G. 2000. Study the present status of school libraries in Ardabil province and the tendency of students to study non-textbooks. Research on Information Science and Public Libraries, Vol. 9, no. 4: 30-38.

Beatty, S. E. and Ferrell, E. M. 1998. Impulse buying: Modeling its precursors. Journal of Retailing, Vol. 74, no. 2: 161-167. Available at: https://doi.org/10.1016/S00224359(99)80092-X.

Bellenger, D. N. and Korgaonkar, P. K. 1980. Profiling the recreational shopper. Journal of retailing, Vol. 56, no. 3: 77-92. Available at: http://connection.ebscohost.com/c/ articles/4667116/profiling-recreational-shopper.

Bellenger, D. N., Robertson, D. H. and Greenberg, B. A. 1977. Shopping center patronage motives. Journal of Retailing, Vol. 53, no. 2: 29-38.

Bloch, P. H. and Richins, M. L. 1983. A theoretical model for the study of product importance perceptions. Journal of Marketing, Vol. 47, no. 3: 69-81. Available at: https://doi.org/10.2307/1251198.

Bloch, P. H., Ridgway, N. M. and Sherrell, D. L. 1989. Extending the concept of shopping: An investigation of browsing activity. Journal of the Academy of Marketing Science, Vol. 17, no. 1: 13-21. Available at: https://link.springer.com/article/10.1007/BF02726349.

Bloch, P. H., Sherrell, D. L. and Ridgway, N. M. 1986. Consumer search: An extended framework. Journal of Consumer Research, Vol. 13, no. 1: 119-126. Available at: https://academic.oup.com/jcr/article-abstract/13/1/119/1814625.

Brindesi, H., Monopoli, M. and Kapidakis, S. 2013. Information seeking and searching habits of Greek physicists and astronomers: A case study of undergraduate students. Procedia - Social and Behavioral Sciences, Vol. 73: 785-793. Available at: https://doi.org/10.1016/j.sbspro.2013.02.119.

Bronstein, J. 2014. The role of perceived self-efficacy in the information seeking behavior of Library and Information Science Students. The Journal of Academic Librarianship, Vol. 40, no. 2: 101-106. Available at: https://doi.org/10.1016/j.acalib.2014.01.010.

Brown, M., Pope, N. and Voges, K. 2003. Buying or browsing?: An exploration of shopping orientations and online purchase intention. European Journal of Marketing, Vol. 37, no. 11/12: 1666-1684. Available at: https://doi.org/10.1108/03090560310495401.

Burkett, J. 1976. The time factor in library and information management. Journal of Librarianship, Vol. 8, no. 1: 21-32. Available at: https://doi.org/10.1177/ 096100067600800102.

Burnett, S. E. 2006. Internal and external trigger cues of impulse buying online (Master's Thesis). Oregon State University, Corvallis, Oregon USA. Available at: https://ir.library.oregonstate.edu/concern/graduate_thesis_or_dissertations/db78tg0 $7 w$ ?locale $=e n$.

Chen, Y. F. and Wang, R. Y. 2016. Are humans rational? Exploring factors influencing impulse buying intention and continuous impulse buying intention. Journal of 
Consumer Behaviour, Vol. 15, no. 2: 186-197. Available at: https://doi.org/10.1002/cb.1563.

Clover, V. T. 1950. Relative importance of impulse-buying in retail stores. Journal of Marketing, Vol. 15, no. 1: 66-70. Available at: https://doi.org/10.2307/1247083.

Darrat, A. A., Darrat, M. A. and Amyx, D. 2016. How impulse buying influences compulsive buying: The central role of consumer anxiety and escapism. Journal of Retailing and Consumer Services, Vol. 31: 103-108. Available at: https://doi.org/10.1016/j.jretconser.2016.03.009.

Donovan, R. J. and Rossiter, J. R. 1982. Store atmosphere: An environmental psychology approach. Journal of Retailing, Vol. 58, no. 1: 34-57. Available at: https://www.researchgate.net/publication/248766608.

Donovan, R. J., Rossiter, J. R., Marcoolyn, G. and Nesdale, A. R. 1994. Store atmosphere and purchasing behaviour. Journal of Retailing, Vol. 70, no. 3: 283-294.

Elliott, R. 1994. Addictive consumption: Function and fragmentation in postmodernity. Journal of Consumer Policy, Vol. 17, no. 2: 159-179. Available at: https://doi.org/10.1007/BF01016361.

Engel, J. F., Blackwell, R. D. and Miniard, P. W. 1994. Consumer behavior (8th edition). Fort Worth: Dryden Pr.

Floh, A. and Madlberger, M. 2013. The role of atmospheric cues in online impulse-buying behavior. Electronic Commerce Research and Applications, Vol. 12, no. 6: 425-439. Available at: https://doi.org/10.1016/j.elerap.2013.06.001.

Foroughi, A., Buang, N. A., Senik, Z. C. and Hajmisadeghi, R. S. 2013. Impulse buying behavior and moderating role of gender among Iranian shoppers. Journal of Basic and Applied Scientific Research, Vol. 3, no. 4: 760-769.

Fulton, C. 2009. The pleasure principle: the power of positive affect in information seeking. Aslib Proceedings, Vol. 61, no. 3: 245-261. Available at: https://doi.org/10.1108/ 00012530910959808.

Ghanavizchi, M. A. and Davarpanah, M. R. 2008. Evaluating the factors facilitating and preventing the study and the relationship between attitude to study and reading books with Maslow's motivational model. Journal of Library and Information Science, Vol. 10, no. 4: 89-110.

Ghavidel, S. and Gilvari, A. 2016. Librarians and positive thinking skills: A case study of central university libraries affiliated to Iran Ministry of Science, Research and Technology (MSRT) in Tehran. International Journal of Information Science and Management, Vol. 14, no. 2: 47-57.

Gowda, V. and Shivalingaiah, D. 2010. Information seeking patterns of researchers in the university libraries in Karnataka State. SRELS Journal of Information Management, Vol. 47, no. 1: 83-101. https://doi.org/10.17821/srels/2010/v47i1/44955.

Graa, A. and Dani-Elkebir, M. 2012. Application of stimulus \& response model to impulse buying behavior of Algerian consumers. Serbian Journal of Management, Vol. 7, no. 1: 53-64. https://doi.org/10.5937/sjm1201053G.

Gupta, S., Heng, X. and Sahu, V. 2009. Impact of store size on impulse purchase. IUP Journal of Marketing Management, Vol. 8, no. 1: 7-22.

Halder, S., Roy, A. and Chakraborty, P. K. 2010. The influence of personality traits on information seeking behaviour of students. Malaysian Journal of Library \& Information Science, Vol. 15, no. 1: 41-53.

Haque, E., Rahman, A. and SK, A. 2016. Information seeking behaviour of Faculty members and research scholar of Agricultural University Libraries in Bangladesh. Research Journal of Library Sciences, Vol. 4, no. 2: 1-8. Available at: http://www.isca.in/RJLS/Archive/v4/i2/1.ISCA-RJLS-2016-002.php. 
Harati, H., Nooshinfard, F., Isfandyari-Moghaddam, A., Babalhavaeji, F. and Hariri, N. 2019. Factors affecting the unplanned use behavior of academic libraries users. Aslib Journal of Information Management, Vol. 71, no. 2: 138-154. Available at: https://doi.org/10.1108/AJIM-04-2018-0092.

Harmancioglu, N., Finney, R. Z. and Joseph, M. 2009. Impulse purchases of new products: an empirical analysis. Journal of Product \& Brand Management, Vol. 18, no. 1: 27-37. Available at: https://doi.org/10.1108/10610420910933344.

Hausman, A. 2000. A multi-method investigation of consumer motivations in impulse buying behavior. Journal of Consumer Marketing, Vol. 17, no. 5: 403-426. Available at: https://doi.org/10.1108/07363760010341045.

Hirschman, E. C. and Holbrook, M. B. 1982. Hedonic consumption: Emerging concepts, methods and propositions. Journal of Marketing, Vol. 46, no. 3: 92-101. Available at: https://doi.org/10.2307/1251707.

Hooman, H. 2005. Structural equation modeling with LISREL application (1st ed.). Tehran: SAMT Inc. [In Persian].

Houston, M. J. and Rothschild, M. L. 1978. Conceptual and methodological perspectives in involvement. Educators' Proceedings (pp. 186-187). Chicago: American Marketing Association.

Hoyer, W. D. and Maclnnis, D. J. 2008. Consumer behavior (5 ed.). Chula Vista: SouthWestern College Pub.

Husnain, M., Rehman, B., Syed, F. and Akhtar, M. W. 2018. Personal and in-store factors influencing impulse buying behavior among generation $Y$ consumers of small cities. Business Perspectives and Research, Vol. 7, no. 1: 92-107. Available at: https://doi.org/10.1177/2278533718800625.

Imbayani, I. G. A. and Novarini, N. N. A. 2018. Influence of shopping lifestyle, fashion involvement dan positive emotion terhadap impulse buying behavior. Jurnal IImiah Manajemen dan Bisnis, Vol. 3, no. 2: 199-210. Available at: http://journal.undiknas.ac.id/index.php/manajemen/article/view/2138.

Isen, A. M. and Reeve, J. 2005. The influence of positive affect on intrinsic and extrinsic motivation: Facilitating enjoyment of play, responsible work behavior, and selfcontrol. Motivation and Emotion, Vol. 29, no. 4: 295-323. Available at: https://doi.org/10.1007/s11031-006-9019-8.

Jarboe, G. R. and McDaniel, C. D. 1987. A profile of browsers in regional shopping malls. Journal of the Academy of Marketing Science, Vol. 15, no. 1: 46-53. Available at: https://doi.org/10.1007/BF02721953.

Jiang, Y. and Wang, C. L. 2006. The impact of affect on service quality and satisfaction: The moderation of service contexts. Journal of Services Marketing, Vol. 20, no. 4: 211-218. Available at: https://doi.org/10.1108/08876040610674562.

Jones, M. A., Reynolds, K. E., Weun, S. and Beatty, S. E. 2003. The product-specific nature of impulse buying tendency. Journal of Business Research, Vol. 56, no. 7: 505-511. Available at: https://doi.org/10.1016/S0148-2963(01)00250-8.

Kacen, J. J. and Lee, J. A. 2002. The influence of culture on consumer impulsive buying behavior. Journal of Consumer Psychology, Vol. 12, no. 2: 163-176. Available at: https://www.sciencedirect.com/science/article/abs/pii/S1057740802702325.

Kapferer, J.-N. and Laurent, G. 1985. Consumer involvement profiles: A new and practical approach to consumer involvement. Journal of Advertising Research, Vol. 25, no. 6: 48-56. Available at: https://ideas.repec.org/p/hal/journl/hal-00786782.html.

Katebi, S. 1973. Study the habits and interest of students to study (Master's Thesis) Faculty of Educational Sciences, University of Tehran, Tehran, Iran. 
Kaur, P. and Singh, R. 2007. Uncovering retail shopping motives of Indian youth. Young Consumers, Vol. 8, no. 2: 128-138. Available at: https://doi.org/10.1108/ 17473610710757491.

Khan, F. D., Ahmad, S. and Khan, A. 2017. Information seeking behaviour (ISB) of teaching staff and students using central library of the University of Peshawar. PUTAJ Humanities and Social Sciences, Vol. 25, no. 1; 145-160.

Kiani, H., Rezaei Sharifabadi, S. and Sam, S. 2010. Evaluating the study status of employed women and housewives in Shiraz. Journal of Library and Information Science, Vol. 13, no. 1: 133-150.

Kim, J. 2003. College students' apparel impulse buying behaviors in relation to visual merchandising (Master's thesis). University of Georgia, Athens, Georgia, USA. Available at: https://athenaeum.libs.uga.edu/handle/10724/21084.

Koufaris, M. 2002. Applying the Technology Acceptance Model and Flow Theory to online consumer behavior. Information Systems Research, Vol. 13, no. 2: 205-223. Available at: https://www.jstor.org/stable/23011056.

Koufaris, M., Kambil, A. and LaBarbera, P. A. 2001. Consumer behavior in web-based commerce: An empirical study. International Journal of Electronic Commerce, Vol. 6, no. 2: 115-138. Available at: https://www.jstor.org/stable/27751014.

Kumar, A., Salmani, N. and Baweja, S. 2014. Information seeking behaviour by the research scholars and faculty members: A survey study of Kurukshetra University Kurukshetra in the disciplines of life science. IOSR Journal of Humanities and Social Science, Vol. 19, no. 6: 119-138. Available at: https://doi.org/10.9790/0837-1964119138.

Kumar, K. and Tholkappian, s. 2013. Information seeking behaviour of library users in women's educational institutions: A survey. International Research : Journal of Library and Information Science, Vol. 3, no. 4.

Lopatovska, I. and Arapakis, I. 2011. Theories, methods and current research on emotions in library and information science, information retrieval and human-computer interaction. Information Processing \& Management, Vol. 47, no. 4: 575-592. Available at: https://doi.org/10.1016/j.ipm.2010.09.001.

Maulana, A., Mukhlis and Novalia, N. 2019. The effect of shopping life style and positive emotion on buying impulse (Case study of the Palembang City Hypermarket). Information Management and Business Review, Vol. 11, no. 1: 17-23. Available at: https://doi.org/10.22610/imbr.v11i1.2844.

Mavodza, J. 2011. Information seeking behaviour of library users at Metropolitan College of New York. Reference Services Review, Vol. 39, no. 4: 643-653. Available at: https://doi.org/10.1108/00907321111186668.

Mihić, M. and Kursan, I. 2010. Influence of demographic and individual difference factors on impulse buying. Tržište/Market, Vol. 22, no. 1: 7-28. Available at: https://econpapers.repec.org/article/zagmarket/v_3a22_3ay_3a2010_3ai_3a1_3ap_3 a7-28.htm.

Moe, W. W. 2003. Buying, searching, or browsing: Differentiating between online shoppers using in-store navigational clickstream. Journal of Consumer Psychology, Vol. 13, no. 1: 29-39. Available at: https://doi.org/10.1207/S15327663JCP13-1\&2_03.

Mohammadzadeh, H. and Bozorgi, A. 2013. Users of the National Library of Iran and their methods for using the resources and services of the National Library: Is it in accord with the library's statute or not? National Studies on Librarianship and Information Organization, Vol. 23, no. 4: 22-39.

Mohan, G., Sivakumaran, B. and Sharma, P. 2013. Impact of store environment on impulse buying behavior. European Journal of Marketing, Vol. 47, no. 10: 1711-1732. Available at: https://doi.org/10.1108/EJM-03-2011-0110. 
Mohd Saad, M. S. and Zainab, A.N. 2009. An investigation of information seeking behaviour of Computer Science and Information Technology undergraduates: a qualitative approach. Malaysian Journal of Library \& Information Science, Vol. 14, no. 3: 15-34.

Mohseni Kabir, T. 1999. The method of promoting and developing the habit of studying and reading in children, adolescents, students and families. Journal of Academic Librarianship and Information Research, Vol. 30, no. 28-29: 137-144.

Mumtaz, S. 2001. Children's enjoyment and perception of computer use in the home and the school. Computers \& Education, Vol. 36, no. 4: 347-362. Available at: https://doi.org/10.1016/S0360-1315(01)00023-9.

Ngozi, O. V., Uche, E. U. and Ejiro, A. K. 2015. Information seeking behaviour of faculty members in a Nigerian university. International Journal of Academic Research and Reflection, Vol. 3, no. 4: 95-102.

Novak, T. P., Hoffman, D. L. and Yung, Y. F. 2000. Measuring the customer experience in online environments: A structural modeling approach. Marketing Science, Vol. 19, no. 1: 22-42. Available at: https://doi.org/10.1287/mksc.19.1.22.15184.

O'Brien, H. L., Dickinson, R. and Askin, N. 2017. A scoping review of individual differences in information seeking behavior and retrieval research between 2000 and 2015. Library \& Information Science Research, Vol. 39, no. 3: 244-254. Available at: https://doi.org/10.1016/j.lisr.2017.07.007.

Olsen, S. O., Tudoran, A. A., Honkanen, P. and Verplanken, B. 2016. Differences and similarities between impulse buying and variety seeking: A personality-based perspective. Psychology \& Marketing, Vol. 33, no. 1: 36-47. Available at: https://doi.org/10.1002/mar.20853.

Ozer, L. and Gultekin, B. 2015. Pre- and post-purchase stage in impulse buying: The role of mood and satisfaction. Journal of Retailing and Consumer Services, Vol. 22: 71-76. Available at: https://doi.org/10.1016/j.jretconser.2014.10.004.

Park, E. J., Kim, E. Y. and Forney, J. C. 2006. A structural model of fashion-oriented impulse buying behavior. Journal of Fashion Marketing and Management: An International Journal, Vol. 10, no. 4: 433-446. Available at: https://doi.org/10.1108/ 13612020610701965.

Peck, J. and Childers, T. L. 2006. If I touch it I have to have it: Individual and environmental influences on impulse purchasing. Journal of Business Research, Vol. 59, no. 6: 765769. Available at: https://doi.org/10.1016/j.jbusres.2006.01.014.

Pors, N. O. 2005. Changing perceptions and attitudes among Danish library managers and directors: The influence of environmental factors. New Library World, Vol. 106, no. 3/4: 107-115. Available at: https://doi.org/10.1108/03074800510587327.

Qasim, O. A. and Noormohammadi, H. A. 2016. Patterns of measured study capita in Iran. Paper presented at the Eighth National Conference and the Second International Conference on Knowledge Management, Tehran: Information Institute in Oil, Gas and Petrochemical.

Riding, R. and Rayner, S. 1998. Cognitive styles and learning strategies: Understanding Style differences in learning and behavior. London \& New York: Routledge.

Rook, D. W. 1987. The buying impulse. Journal of Consumer Research, Vol. 14, no. 2: 189199. Available at: https://doi.org/10.1086/209105.

Rook, D. W. and Fisher, R. J. 1995. Normative influences on impulsive buying behavior. Journal of Consumer Research, Vol. 22, no. 3: 305-313. Available at: https://www.jstor.org/stable/2489616.

Rook, D. W. and Hoch, S. J. 1985. Consuming impulses. NA - Advances in Consumer Research, Vol. 12: 23-27. Available at: http://acrwebsite.org/volumes/6351/ volumes/v12/NA-12. 
Rowley, J. 2002. Window shopping and browsing opportunities in cyberspace. Journal of Consumer Behaviour, Vol. 1, no. 4: 369-378. Available at: https://doi.org/10.1002/cb.81.

Safi, G. 2001. The impact of public libraries on the development of the study culture. Journal of Academic Librarianship and Information Research, Vol. 32, no. 34: 5-14.

Said, E. N. A., Ahmad, M. H., Hamid, M. and Enegbuma, W. I. 2016. A users' satisfaction on the environmental performance of naturally ventilated library: A structural equation modeling approach. Indian Journal of Science and Technology, Vol. 9, no. 46. Available at: https://doi.org/10.17485/ijst/2016/v9i46/107130.

Salari, M. 2012. Analysis and explanation of the major factors affecting the reading culture of Iran and provide a suitable model for the development (Doctoral dissertation). Faculty of Education and Psychology, Ferdowsi University of Mashhad, Mashhad, Iran.

Salarian, M., Ibrahim, R. and Nemati, K. 2012. The relationship between users cognitive style and information seeking behavior among postgraduate engineering students. Procedia - Social and Behavioral Sciences, Vol. 56: 461-465. Available at: https://doi.org/10.1016/j.sbspro.2012.09.677.

Samaniyan, M. 1998. Study the role of education and schools in education and promoting studying and reading books among the students. Research on Information Science and Public Libraries, Vol. 7, no. 4: 34-39.

Sharma, P., Sivakumaran, B. and Marshall, R. 2010. Impulse buying and variety seeking: A trait-correlates perspective. Journal of Business Research, Vol. 63, no. 3: 276-283. Available at: https://doi.org/10.1016/j.jbusres.2009.03.013.

Sherry, J. F. 1990. A sociocultural analysis of a midwestern American flea market. Journal of Consumer Research, Vol. 17, no. 1: 13-30. Available at: https://doi.org/10.1086/208533.

Shill, H. B. and Tonner, S. 2003. Creating a better place: Physical improvements in academic libraries, 1995-2002. College \& Research Libraries, Vol. 64, no. 6: 431-466. Available at: https://doi.org/10.5860/crl.64.6.431.

Shill, H. B. and Tonner, S. 2004. Does the building still matter? Usage patterns in new, expanded, and renovated libraries, 1995-2002. College \& Research Libraries, Vol. 65, no. 2: 123-150. Available at: https://doi.org/10.5860/crl.65.2.123.

Slama, M. E. and Tashchian, A. 1985. Selected Socioeconomic and demographic characteristics associated with purchasing involvement. Journal of Marketing, Vol. 49, no. $1: 72-82$. Available at: https://doi.org/10.2307/1251177.

Sofi, S. A. and Najar, S. A. 2018. Impact of personality influencers on psychological paradigms: An empirical-discourse of big five framework and impulsive buying behaviour. European Research on Management and Business Economics, Vol. 24, no. 2: 71-81. Available at: https://doi.org/10.1016/j.iedeen.2017.12.002.

Soltani, P. 1978. Praising low reading. The Letter of the Association of Iranian Librarians, Vol. 39, no. 10: 243-250.

Stern, H. 1962. The significance of impulse buying today. Journal of Marketing, Vol. 26, no. 2: 59-62. Available at: https://doi.org/10.2307/1248439.

Sufar, S., Talib, A. and Hambali, H. 2012. Towards a better design: Physical interior environments of public libraries in Peninsular Malaysia. Procedia - Social and Behavioral Sciences, Vol. 42: 131-143. Available at: https://doi.org/10.1016/ j.sbspro.2012.04.174.

Superio, D. L., Canaman, J. B., Jaco, J. P. and Estember, M. L. 2018. The information-seeking behavior of aquaculture researchers at the Southeast Asian Fisheries Development Center. Information Development, Vol. 34, no. 1: 1-16. Available at: https://doi.org/10.1177/0266666917754127. 
Teo, T. S. H. 2001. Demographic and motivation variables associated with Internet usage activities. Internet Research, Vol. 11, no. 2: 125-137. Available at: https://doi.org/10.1108/10662240110695089.

Thanuskodi, S. 2009. Information-seeking behavior of law faculty at Central Law College, Salem. Library Philosophy and Practice (e-journal), Vol. 282: 1-7. Available at: https://digitalcommons.unl.edu/libphilprac/282.

Thindwa, T., Chawinga, W. D. and Dube, G. 2019. Information-seeking behaviour of security studies students: A case study. South African Journal of Information Management, Vol. 21, no. 1: 10. Available at: https://doi.org/10.4102/ sajim.v21i1.1048.

Tremblay, A. J. 2005. Impulse buying behavior: Impulse buying behavior among college students in the borderlands. ETD Collection for University of Texas, El Paso, Texas.

Tuyet Mai, N. T., Jung, K., Lantz, G. and Loeb, S. G. 2003. An exploratory investigation into impulse buying behavior in a transitional economy: A study of urban consumers in Vietnam. Journal of International Marketing, Vol. 11, no. 2: 13-35. Available at: https://doi.org/10.1509/jimk.11.2.13.20162.

Vaezi, M. 2013. Per capita book reading low. (A. Rezvan-Nia, trans.), Irandaily, October 2 2013. p. 7.

Vänniä, E. 2013. Impulse buying behaviour of young males in an airport environment. Arcada University of Applied Sciences, Helsinki.

Veatch, L. 1987. Toward the environmental design of library buildings. Library Trends, Vol. 36, no. 2: 361-376. Available at: https://eric.ed.gov/?id=EJ366400.

Virvilaitè, R., Saladienè, V. and Bagdonaite, R. 2009. Peculiarities of impulsive purchasing in the market of consumer goods. Engineering Economics, Vol. 62, no. 2: 101-108. Available at: http://inzeko.ktu.lt/index.php/EE/article/view/11633.

Wakefield, K. L. and Baker, J. 1998. Excitement at the mall: Determinants and effects on shopping response. Journal of Retailing, Vol. 74, no. 4: 515-539. Available at: https://doi.org/10.1016/\$0022-4359(99)80106-7.

Wanberg, C. R. and Banas, J. T. 2000. Predictors and outcomes of openness to changes in a reorganizing workplace. The Journal of Applied Psychology, Vol. 85, no. 1: 132-142. Available at: https://www.ncbi.nlm.nih.gov/pubmed/10740964.

Weinberg, P. and Gottwald, W. 1982. Impulsive consumer buying as a result of emotions. Journal of Business Research, Vol. 10, no. 1: 43-57. Available at: https://doi.org/10.1016/0148-2963(82)90016-9.

Wu, K. C. 2015. Affective surfing in the visualized interface of a digital library for children. Information Processing \& Management, Vol. 51, no. 4, pp. 373-390. Available at: https://doi.org/10.1016/j.ipm.2015.02.005.

Wu, W. C. and Huan, T. C. 2010. The effect of purchasing situation and conformity behavior on young students impulse buying. African Journal of Business Management, Vol. 4, no. 16: 3530-3540. Available at: https://academicjournals.org/journal/AJBM/articleabstract/D5140C521385.

Xiang, L., Zheng, X., Lee, M. K. O. and Zhao, D. 2016. Exploring consumers' impulse buying behavior on social commerce platform: The role of parasocial interaction. International Journal of Information Management, Vol. 36, no. 3: 333-347. Available at: https://doi.org/10.1016/j.ijinfomgt.2015.11.002.

$\mathrm{Xu}, \mathrm{Y}$. 2007. Impact of store environment on adult generation $\mathrm{Y}$ consumers' impulse buying. Journal of Shopping Center Research, Vol. 14, no. 1: 39-56. Available at: http://connection.ebscohost.com/c/articles/62287277.

Xuanxiaoqing, F., Yang, D. J. and Huang, K. C. 2012. A study of the factors that affect the impulsive cosmetics buying of female consumers in Kaohsiung. African Journal of 
Business Management, Vol. 6, no. 2: 652-657. Available at: https://doi.org/10.5897/AJBM11.2187.

Youn, S. and Faber, R. J. 2000. Impulse buying: Its relation to personality traits and cues. Advances in Consumer Research, Vol. 27: 179-185. Available at: http://acrwebsite.org/volumes/8383/volumes/v27/NA-27.

Zaichkowsky, J. L. 1994. The personal involvement inventory: Reduction, revision, and application to advertising. Journal of Advertising, Vol. 23, no. 4: 59-70. Available at: https://doi.org/10.1080/00913367.1943.10673459.

Zhao, Z., Du, X., Liang, F. and Zhu, X. 2019. Effect of product type and time pressure on consumers' online impulse buying intention. Journal of Contemporary Marketing Science, Vol. 2, no. 2: 137-154. Available at: https://doi.org/10.1108/JCMARS-012019-0012

Zhong, Z., Hu, D., Zheng, F., Ding, S. and Luo, A. 2018. Relationship between informationseeking behavior and innovative behavior in Chinese nursing students. Nurse Education Today, Vol. 63: 1-5. Available at: https://doi.org/10.1016/ j.nedt.2018.01.004. 